\title{
Measurement of plasma group I pepsinogens
}

\author{
D. F. LEVINE \\ M.B., M.R.C.P. (U.K.) \\ M. BEER \\ B.Sc., M.Sc. \\ Metabolic Laboratory, London Hospital Medical College and The London Hospital, Whitechapel, \\ London E1 $1 B B$
}

\begin{abstract}
Summary
Plasma group I pepsinogen (PG I) concentration is now a readily available non-invasive marker of gastric secretory function, with several potentially useful applications.

Ninety-eight percent of control subjects had a plasma PG I below $115 \mathrm{ng} / \mathrm{ml}$ while values above this level were seen in $43 \%$ of duodenal ulcer patients. Plasma PG I levels below the observed normal lower limit of $30 \mathrm{ng} / \mathrm{ml}$ were seen consistently in patients with documented achlorhydria or pernicious anaemia.

In 48 patients with a variety of upper gastrointestinal disorders there was a significant correlation between PG I pepsinogens and pentagastrin-stimulated maximal acid output.

Changes in plasma PG I promise to be useful in evaluating both operations on the vagus and newer anticholinergic drugs, whilst in epidemiological and family studies these measurements seem well suited to explore duodenal ulcer heterogeneity.
\end{abstract}

KEY WORDS: duodenal ulcer, gastric acid, pernicious anaemia.

\section{Introduction}

Agar gel electrophoresis of human gastric mucosal extracts yields proteolytic fractions, numbered 1-8 in decreasing order of electrophoretic mobility. The seven fastest fractions have characteristics of pepsinogens, with proteolytic activity resistant to alkalinization but destroyed by sequential acidification and neutralization (Samloff, 1969).

Fractions 1-5 inclusive are designated group I pepsinogens (PG I) and originate solely from the chief and mucous neck cells of the gastric oxyntic mucosa (Samloff, 1971). Fractions 6 and 7 are the group II pepsinogens and are found also in pyloric and Brunner's glands (Samloff and Liebman, 1973).

Radioimmunoassay of PG I in serum was first described by Samloff and Liebman in 1974. Samloff was later able to show a correlation between serum PG I and histamine-stimulated peak acid output
(PAO) (Samloff, Secrist and Passaro, 1975b). High $\stackrel{3}{3}$. serum levels of PG I have been found in approxi-:

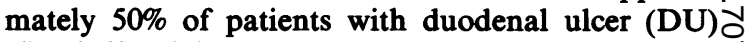
(Samloff, Liebman and Panitch, 1975a). In some. ㄱ families, a high serum PG I level is inherited as ano autosomal dominant character (Rotter et al., 1979)

Serum PG I levels are not affected by small test meals (Waldum, Straume and Burhol, 1979) and $\vec{c}$ after more substantial meals a maximum rise of $\mathbb{D}$ about $8 \%$ has been reported (Samloff et al., 1975a). $\frac{\vec{D}}{\mathrm{D}}$ PG $I$ are excreted in urine and high levels occur in 3 patients with renal failure (Samloff and Townę, Ф 1970). Pregnancy is reported to have no significas $t \vec{t}$ effect on serum PG I (Waldum, Straume ando Lundgren, 1980). Samples taken with subjects starg. ing may give slightly higher results than those taken supine (Waldum, Jorde and Gunnes, 1982).

There have been no published accounts from $\overline{0}$ Britain of plasma PG I measurements. This study is an attempt to evaluate plasma PG I as a non-invasive $\varrho$ test of gastric secretory potential and to assess $\overrightarrow{\overrightarrow{0}}$ whether the distribution of plasma PG I concentra- 3 tion in ulcer patients and controls matches that seen in other countries.

\section{Materials and methods}

Venous blood was obtained from several groups of subjects:

(1) Healthy male medical staff and students $(n=17)$ 윽

(2) Healthy female medical students and nurses $(n=17)$ age range $20-45$ years, mean 26.9 years. $N$ All subjects in groups 1 and 2 (designated normal controls) were non-smokers who denied $\stackrel{N}{\circ}$ any history of peptic ulcer or recurrent dyspep- $N$ sia in themselves or first degree relatives. Blood was taken between 8.00 a.m. and 9.00 a.m. aftero overnight fast. No attempt was made to control $\frac{}{\varnothing}$ for posture. Four male subjects had blood taken $\stackrel{?}{?}$ under similar conditions on 3 consecutive days. 
(3) Male medical outpatients with no history of peptic ulcer or recurrent dyspepsia - designated male hospital controls $(n=21)$ age range 18-52 years, mean 32 years.

(4) Ante-natal clinic patients in the third trimester of pregnancy-designated female hospital controls $(n=41)$ age range $18-34$ years, mean $25 \cdot 7$ years. In groups 3 and 4 no attempt was made to control for family history, smoking, time of last meal or time of sampling.

(5) Patients about to undergo upper gastrointestinal endoscopy for investigation of pain or bleeding $(n=47)$. This group included 17 males with DU and 10 females with DU. Male normal endoscopy-11; female normal endoscopy-7.

(6) Patients $(n=48)$ with a variety of upper gastrointestinal disorders about to undergo pentagastrin tests which were performed by the conventional method using $6 \mu \mathrm{g} / \mathrm{kg}$ pentagastrin i.m. Maximal acid output (MAO) was the quantity of acid aspirated in the $1 \mathrm{st} \mathrm{hr}$ after pentagastrin. In this group there were $24 \mathrm{DU}$ patients, $(6$ of these were also listed in group 5), 4 gastric ulcer patients and 17 with dyspepsia but normal upper gastrointestinal endoscopic appearances. Also included were 3 patients found to be achlorhydric.

(7) Six patients with pernicious anaemia.

Blood was collected into heparinized tubes, plasma separated by centrifugation and stored at $-20^{\circ} \mathrm{C}$ until assay which was performed using a commercial radioimmunoassay 'kit' (Pepsik SORIN CIS U.K. Ltd). Manufacturer's instructions were followed but additional tubes were added to check non-specific binding. Counting was done on an LKB Wallac 1260 'Multigamma' counter linked to a Data Dynamics 390 microprocessor and printer.

\section{Results}

Intra- and inter-assay coefficients of variation were 8 and 13\%, respectively, for samples in the control range. Fig. 1 shows the distributions of plasma PG I in normal and hospital controls.

In normal controls there was no significant correlation between plasma PG I and height, weight or calculated lean body mass.

In 4 normal controls plasma PG I varied by less than $5 \%$ when sampled under similar conditions on 3 consecutive days. Fig. 2 shows the distribution of plasma PG I in controls and patients with DU, dyspeptic patients with normal gastroduodenal endoscopy appearances and patients with achlorhydria / pernicious anaemia.

Male and female controls and patients have been grouped together here for clarity and because the sex

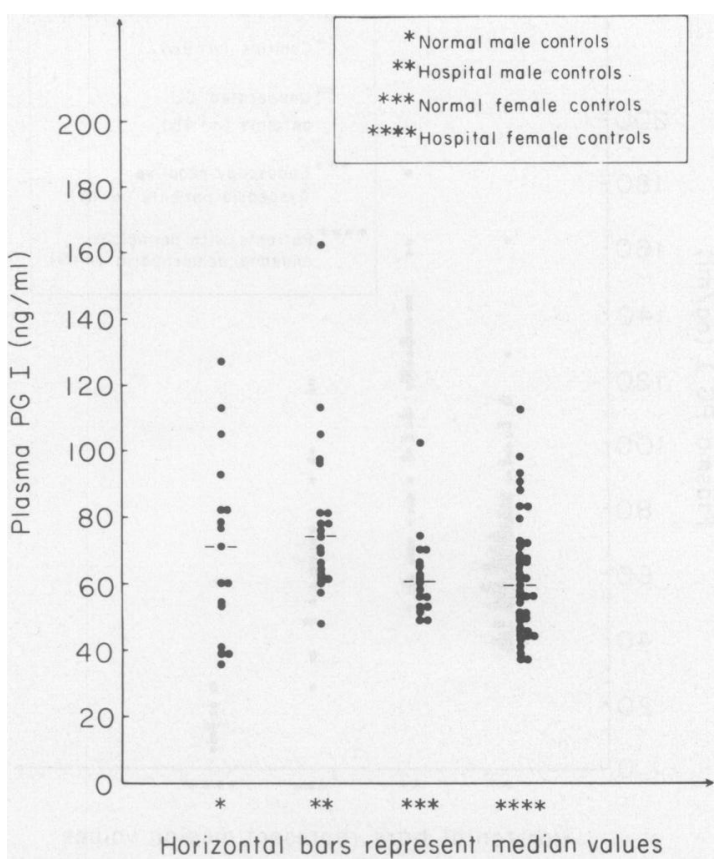

FIG. 1. Distribution of plasma PG I concentration in control subjects.

distribution of plasma PG $I$ in patients was much more similar than in the controls.

It will be noted that all 9 patients with achlorhydria/pernicious anaemia had plasma PG I below $30 \mathrm{ng} / \mathrm{ml}$. The only other subject with a level below $30 \mathrm{ng} / \mathrm{ml}$ was an endoscopy-negative dyspeptic patient in whom, unfortunately, acid studies were not obtained.

Fig. 3 shows the regression of plasma PG I on pentagastrin-stimulated maximal acid output (MAO) for the group of 48 patients with a variety of upper gastrointestinal disorders.

\section{Discussion}

Plasma PG I concentrations in normal control subjects seem to be independent of height, weight and calculated lean body mass, but are generally higher in men than women. Normal controls showed similar PG I concentrations to less rigorously selected hospital controls. Grouping all male and female controls, only $2 / 96(2 \cdot 1 \%)$ had plasma PG I concentrations over $115 \mathrm{ng} / \mathrm{ml}$ compared with 19/45 (42.2\%) of patients with DU. Of symptomatic patients found to have normal endoscopic appearances, $2 / 18(11 \cdot 1 \%)$ had plasma PG I over $115 \mathrm{ng} / \mathrm{ml}$, making it unlikely that the stress of an anticipated endoscopy caused the elevated PG I in DU patients.

Although there was a very small day-to-day 


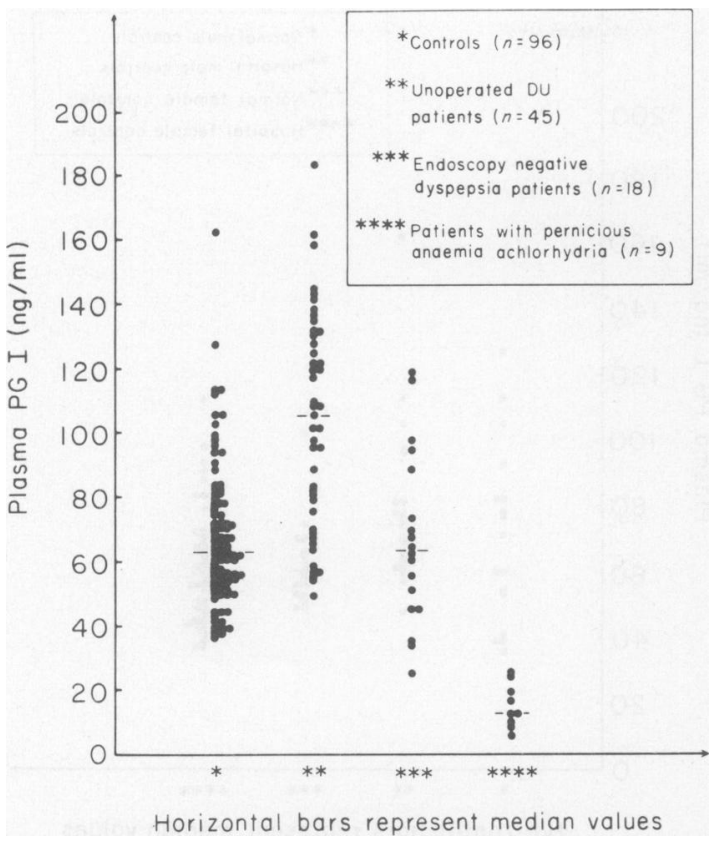

FIG. 2. Distribution of plasma PG I concentration in control subjects and patients with upper gastrointestinal disorders.

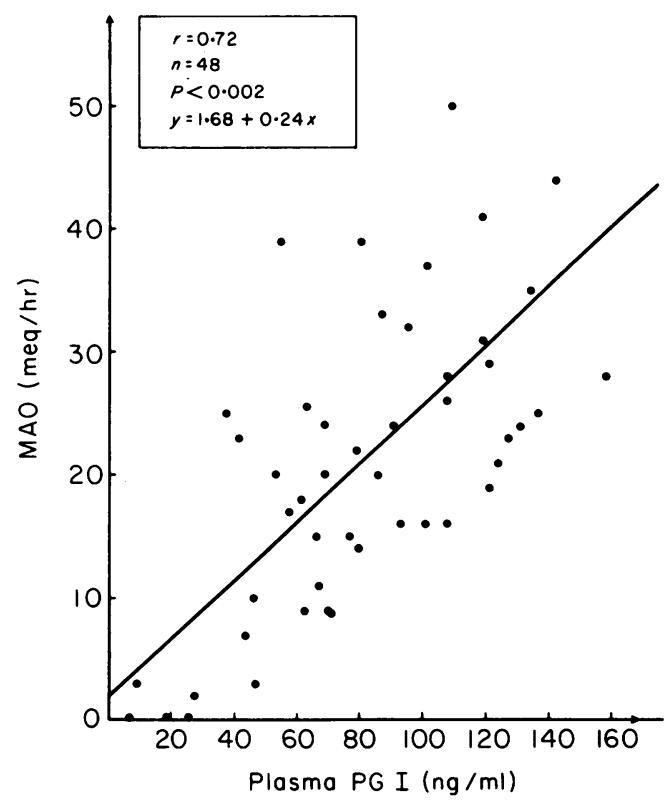

FIG. 3. Regression of plasma PGI concentration on maximal acid output (MAO) for patients with upper gastrointestinal disorders.

variation of plasma PG I in normal controls under basal conditions, there was more variation with time in the few DU patients so studied, although with no obvious relationship to ulcer activity. This warrants further study, as a direct correlation between activity of DU and acid/pepsin secretion has been reported (Achord, 1981).

Although there is seldom any need for measurements of plasma PG I (or gastric acid output) in the initial diagnosis and management of individual patients, such a readily available non-invasive marker has several potential applications. It has already been suggested that for indentification of ulcer recurrence after surgery, serum PG $I$ is as useful as acid secretory tests, which, after gastric surgery may be particularly subject to errors (Stabile et al., 1978).

For a heterogeneous group of patients there was a significant correlation between plasma PG I and pentagastrin-stimulated MAO. These data resemble those of Samloff for Histalog-stimulated PAO (Samloff et al., 1975b) and support the contention that plasma PG I concentrations tend to reflect steadystate gastric acid secretory capacity.

Although this could prove clinically useful, it may also be worth considering the circumstances in which of pepsinogen and acid differ. It is still not clear by what $\mathbb{D}$

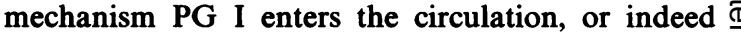
whether plasma PG I more accurately reflects muco- 흥 sal pepsinogen synthesis or storage (Waldum, Burhor and Straume, 1978; Waldum and Burhol, 1980). Aci $\overrightarrow{0}$ and pepsinogen probably have different responses te $\stackrel{\circ}{\oplus}$ some stimuli. Cimetidine treatment has no consisten effect on plasma PG I concentration (Gledhill, personal communication) and it has been reported that, at least gastric, peptic activity may particularly reflect vagal activity (Elder and Smith, 1975; Gabryelewicz, Laszewicz and Sarosiek, 1980). More work is needed to clarify the relationship of plasma PG I to intragastric peptic activity (Stabile et al., 1978).

\section{Acknowledgments}

We would like to thank Sister G. Keenan and her staff for so carefully performing the pentagastrin tests.

We are also grateful to CIS (U.K.) Ltd for the provision of PEPSIK kits.

\section{References}

ACHORD, J.L. (1981) Gastric pepsin and acid secretion in patients with acute and healed duodenal ulcer. Gastroenterology, 81, 15. ElDER, J.B. \& SMITH, I.S. (1975) Gastric acid output, pepsin output and lean body mass in normal and duodenal-ulcer subjects. $N$ Lancet, i, 1000.

GABRYElewiCZ, A., LASZEWICZ, W. \& SARosieK, J. (1980) The N influence of various secretory inhibitors on peptic activity. $N$ Scandinavian Journal of Gastroenterology, 66 (15), 79.

RotTer, J.I., SONES, J.Q., SAMlofF, I.M., RICHARSON, C.T., GuRSKY, J.M., WALSH, J.H. \& RIMOIN, D.L. (1979) Duodenal-ulcer 0 disease associated with elevated serum pepsinogen. I. An inherited $\frac{C}{\square}$ autosomal disorder. New England Journal of Medicine, 300, 63.

SAMLOFF, I.M. (1969) Slow moving protease and the seven pepsinogens. Electrophoretic demonstration of the existence of 
eight proteolytic fractions in human gastric mucosa. Gastroentero$\log y, 57,659$.

SAMLOFF, I.M. (1971) Cellular localisation of group I pepsinogens in human gastric mucosa by immunofluorescence. Gastroenterology, 61, 185.

SAMLOFF, I.M. \& LiEBMAN, W.M. (1973) Cellular localisation of the group II pepsinogens in human stomach and duodenum by immunofluorescence. Gastroenterology, 65, 36.

SAMLOFF, I.M. \& LiebMAN, W.M. (1974) Radioimmunoassay of group I pepsinogens in serum. Gastroenterology, 66, 494.

Samloff, I.M. , Liebman, W.M. \& Panitch, N.M. (1975a) Serum group I pepsinogens by radioimmunoassay in control subjects and patients with peptic ulcer. Gastroenterology, 69, 83.

SAmloff, I.M., SeCrist, D.M. \& PASSARo, E. (1975b) A study of the relationship between serum group I pepsinogen levels and gastric acid secretion. Gastroenterology, 69, 1196.

SAMLOFF, I.M. \& TOWNES, P.L. (1970) Electrophoretic heterogeneity and relationships of pepsinogens in human urine, serum and gastric mucosa. Gastroenterology, 58, 462.

Stabile, B.E., Passard, E., SAmloff, I.M. \& Walsh, J.H. (1978) Serum pepsinogen $\mathrm{I}$, serum gastrin, and gastric acid output in postoperative recurrent peptic ulcer. Archives of Surgery, 113, $1136(8)$.

Waldum, H.L., Burhol, P.G. \& STRaume, B.K. (1978) Serum group I pepsinogens and gastrin in relation to gastric $\mathrm{H}^{+}$and pepsin outputs before and after subcutaneous injections of pentagastrin. Scandinavian Journal of Gastroenterology, 13, 943.

Waldum, H.L., Straume, B.K. \& BURhOl, P.G. (1979) Radioimmunoassay of group I pepsinogens (PG I) and the effect of food on serum PG I. Scandinavian Journal of Gastroenterology, 14, 241.

WALDUM, H.L. \& BURHOL, P.G. (1980) The effect of somatostatin on serum group I pepsinogens (PG I), serum gastrin, and gastric $\mathrm{H}^{+}$and pepsin secretion in man. Scandinavian Journal of Gastroenterology, 15, 425.

Waldum, H.L., Straume, B.K. \& Lundgren, R. (1980) Serum group I pepsinogens during pregnancy. Scandinavian Journal of Gastroenterology, 15, 61.

WALDUM, H.L., JORDE, R. \& GUNNES, P. (1982) Renal excretion of and the effect of posture on serum group I pepsinogens. Scandinavian Journal of Gastroenterology, 17, 253.

(Accepted 15 March 1984) 